\title{
Geochemical Processes and Assessment of Water Quality for Irrigation of Al-Shagaya Field-C, Kuwait
}

\author{
Al-Ruwaih F.M., Shafiullah G. \\ Department of Earth and Environmental Sciences, Kuwait University, Kuwait
}

\begin{abstract}
Al-Shagaya Field-C is located southwest of Kuwait City, where the brackish groundwater is produced from the Dammam aquifer. The main objectives are to recognize the major geochemical processes operating in the aquifer and controlling its quality; in addition, to evaluate the groundwater quality criteria for drinking and irrigation. The investigation was carried out by estimating $p H, E C, T D S, T H, S A R, \% N a, R S C, R S B C$, potential salinity, magnesium ratio, chloro-alkaline index, Kelly's ratio, Permeability index, and salinity hazard respectively. The TDS ranges between 2474 and 3232 $\mathrm{mg} / \mathrm{l}$, with an average value of $2753 \mathrm{mg} / \mathrm{l}$ and the water is exceeding very hard. Groundwater shows $\mathrm{Ca}-\mathrm{Cl}$ and $\mathrm{Ca}$ $\mathrm{Mg}-\mathrm{Cl}$ genetic water types. Results revealed that the groundwater is oversaturated with respect to dolomite and calcite and under-saturated with respect to gypsum and anhydrite. The main geochemical processes controlling groundwater chemistry in the study area are due to dissolution/ precipitation process along the path flow. The major ions composition in groundwater of the study area indicated that the water is not suitable for drinking. However, the irrigation parameters revealed that the groundwater is suitable for irrigation purposes.
\end{abstract}

Keywords-Dammam aquifer, saturation index, Gibb's ratio, hydro chemical facies \& GIS.

\section{INTRODUCTION}

Kuwait covers an area of $18,000 \mathrm{~km}^{2}$ and lies in the northeastern corner of the Arabian Peninsula and occupies the north-western part of the Arabian Gulf as shown in Fig (1A).The climate is extremely hot and dry in summer and mild to cold in winter. The rainfall is scarce with an annual average precipitation of $115 \mathrm{~mm}$. The average evaporation is equal $17 \mathrm{~mm} /$ day .The location of Kuwait within the arid gives groundwater great importance. The brackish groundwater in Kuwait is used in agriculture, gardening and domestic purposes. Moreover, it is blend with the fresh water produced by desalination plants to make potable drinking water. The groundwater is abstracted from two main aquifers, the Kuwait Group aquifer, which is leaky to water-table aquifer, and the Dammam aquifer is confined to semi-confined aquifer. Al- shagaya area is located in the southwest of Kuwait and was put in use in early 1970's . This area includes five water well fields. Fields A, B, C, D, and E supply Kuwait city with brackish groundwater produced mainly from Dammam aquifer at a peak rate of 60 MIGD, with an expected quality of 4,000 mg/l of TDS, from a total of 115 production wells distributed over the five water-well fields. The salinity of the Dammam aquifer increases from southwest to north-northeast ranging from 2,500 to, 8,000 $\mathrm{mg} / 1$.The major hydro chemical water types are $\mathrm{CaSO}_{4}$, $\mathrm{Na}_{2} \mathrm{SO}_{4}$ and $\mathrm{NaCl}$ [1]. Field-C is the area under investigation, where Figs. $1 \mathrm{~B}$ and $1 \mathrm{C}$ show the location and the distribution of the water wells. Al-Shagaya Field-C is located approximately $64 \mathrm{~km}$ to the south-west of Kuwait City, with 32 wells produced groundwater from the Dammam aquifer.

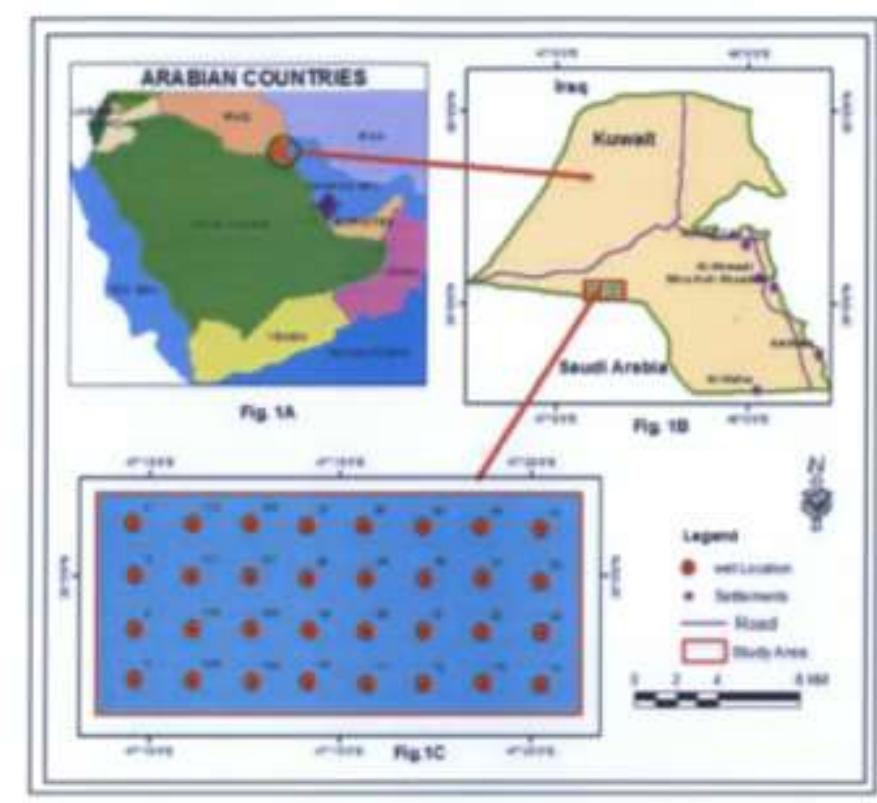

Fige 1A: Location map of Kuwait.

Fig. 1B: Lecation map of the study aren.

Fig. IC: Lecation map of the water wells.

The objectives of this investigation are to identify the water chemical types and hydro chemical processes operating within the main aquifer, in addition to the determination of degree of saturation of groundwater with 
respect to some minerals. Moreover, the suitability of groundwater for drinking and irrigation purposes will be carried out.

Several studies were conducted to date addressing water quality criteria for irrigation. In the research paper published by [2] six soil samples were collected during pre and post monsoon season from Coring mangrove region of East Godavari estuaries for physicochemical of pH, EC, TDS, TH, $\mathrm{Cl}^{-}, \mathrm{SO}_{4}{ }^{2-}, \mathrm{NO}_{3}{ }^{-}, \mathrm{PO}_{4}{ }^{3-}, \mathrm{Na}^{+}, \mathrm{K}^{+}, \mathrm{Ca}^{2+}$, and $\mathrm{Mg}^{2+}$, and irrigation parameters such $\% \mathrm{Na}, \mathrm{SAR}$, $\mathrm{RSC}, \mathrm{KR}$, and $\mathrm{MH}$, were determined. The results showed that the $\mathrm{pH}$ ranges from $7.2-7.8$ and $7.0-7.5$ and indicate slight alkaline nature of the soils. Total hardness ranges from 400 - $1550 \mathrm{mg} / \mathrm{l}$ pre and post monsoon indicating the hardness of soils. The Magnesium Hazard (MH) ranges from 61.93 - 93.4 pre and post monsoon, exceeding the permissible limit of irrigation standards. Higher Magnesium level in soil causes Magnesium Hazard, so that the soil fertility will be depleted and affects the crop yields. According to [3] Salinity and Sodicity have been reported among the major problems of irrigated agriculture across the world. The methods that are commonly used as indices of salinity or sodicity in the soils include electrical conductivity, Sodium Adsorption Ratio (SAR) and Exchangeable Sodium Percentage. Also, [4] found that the effect of high SAR can be poor soil tith, and soils become sticky when wet resulting in reduced water infiltration. Aza-Gnandji et. al. [5] found that high salinity levels tend to affect soil structure and crop productivity. And chloride is an essential plant micronutrient, but, it's toxic to some crops at higher concentration. Sodium is important to some plant growth, and at high concentrations, it is toxic to many plants. The high salinity of water of $\mathrm{C}_{4}-\mathrm{S}_{2}$ class permits occasional use and then only under favorable soil and plants of high salt tolerance should be grown. Dastorani et. al. [6] reported that the groundwater resources can be available to help support development, and the limited recharge of groundwater resources is dependent on the amount duration and intensity of rainfall as well as soil properties. According to a study conducted by [7] on the groundwater quality in Abdalli area in Kuwait, it reveals that most of the groundwater samples fall within class $\mathrm{C}_{3}$ $\mathrm{S}_{4}$ in Wilcox salinity hazard diagram, which means poor water quality for irrigation and it can be used in well drained soil. Moreover, with reference to [8], based on Kelly's ratio, water is classified for irrigation. Kelly's ratio of more than 1 indicates excess level of $\mathrm{Na}^{+}$in water. Therefore, water with Kelly's ratio of less than 1 is suitable for irrigation, while those with ratio more than 3 are unsuitable for irrigation. In addition, the authors [9] pointed out that the higher level of TDS confirms the unsuitability of water for drinking and irrigation purposes.
And the presence of magnesium in water would adversely affect the soil quality rendering it unsuitable for cultivation. If $\mathrm{MH}$ is less than 50 the water is safe and suitable for irrigation. However, Narany et al. [10] reported that bicarbonate hazard is usually represented in term of RSC, which shows the tendency for calcium and magnesium to participation as the soil become concentrated. Therefore, the relative proportion of sodium in the water is increased in the form of sodium bicarbonate. According to [11] when electrical conductivity values exceeded the permissible of limits $4000 \mu \mathrm{mhos} / \mathrm{cm}$, the water is considered of salinity nature, and is not suitable for irrigation purposes .

\section{GEOLOGY OF KUWAIT}

\subsection{Topography}

The topography of Kuwait is generally flat, broken by occasional low hills and shallow depressions. Elevations range from sea level in the east to nearly $300 \mathrm{~m}$ in the southwestern corner of the country. The Jal Az-Zor escarpment form one of the main topographic features in Kuwait [12]. The major depression, Wadi Al-Batin is a valley along the western border with 8 to $11 \mathrm{Km}$ and relief of $70 \mathrm{~m}$. The coast lies along the east of the country and sabkha has developed along the coast. In the northeastern part of the country a few barchans dunes up to $25 \mathrm{~m}$ are found $[13,14]$.

\subsection{Stratigraphy}

The stratigraphical column of Kuwait was mainly influenced by the stable shelf condition of the Arabian plate, causing the deposition of shallow water sediments and evaporates. The surface of Kuwait is formed by sedimentary rocks and sediments ranging from Middle Eocene to Recent. The Dammam Formation represents the oldest exposed sedimentary rocks. The Recent deposits of fine-grained beach sands cover southern coast of Kuwait and the Neutral Zone.

Kuwait Group consists of the Dibdibba, Lower Fars, and Ghar Formations in descending order. Dibdibba Formation includes all rocks between the overlaying Holocene deposits. It consists of fluviated sequence of cross-bedded sands and gravel with subordinate intercalations or lenticular bodies of sandy clays, sandstone, conglomerate and siltstone. Lower Fars Formation consists of sands, Quartz, loosely consolidated gravels, clay and marl. The Ghar Formation consists mainly of marine to terrestrial coarse and unconsolidated sand, silt and gravel.

Hasa Group consists of three formations in descending order; Dammam, Rus and Radhuma Formations. Dammam Formation is considered the largest and the most potential productive aquifer of brackish groundwater in Kuwait. Its thickness ranges between 150 and 275 m 
increases towards the northeast. Dammam Formation consists mainly of dolomitic limestone and limestone inter-bedded with shale at the base of the formation, forms the relatively impermeable lower boundary over most of the region. Rus Formation is composed of hard, dense, massive anhydrite and unfossiliferous limestone. Radhuma Formation consists mostly of anhydrite, dolomitic and marly limestone with few fossiliferous horizons [15].

\subsection{Hydrology and Aquifer System}

The most significant aquifer in Kuwait is the TertiaryQuaternary system. These are the upper clastic sediments of the Kuwait Group aquifer, and the Dammam aquifer which are separated by a confining layer of cherts and/or clay [16]. Under natural hydrological conditions, the flow through the Kuwait aquifer is in SW-NE direction, from the main recharge area in Saudi Arabia to the main discharge area in the Arabian Gulf and Shaat Al-Arab. Generally, part of the natural recharge of the Kuwait Group aquifer gains by leakage from the Dammam aquifer, and also comes from infiltration through the wadies and depressions, as well as the lateral flow coming from Saudi Arabia [17]. The effect of leakage between the two main aquifers may give rise to the similarities of groundwater chemistries.

\subsection{Objectives of the Study}

The main objectives are to study the geochemistry of the study area in order to recognize the prevailing and the major geochemical processes that control the quality of the groundwater. Moreover, the suitability of groundwater for drinking and irrigation were evaluated by determining physiochemical and irrigation parameters.

\section{METHODOLOGY}

In this study, the chemical analyses of the major cations and anions such as $\mathrm{Ca}^{2+}, \mathrm{Mg}^{2+}, \mathrm{Na}^{+}, \mathrm{K}^{+}, \mathrm{HCO}_{3}{ }^{-}, \mathrm{SO}_{4}{ }^{2-}$, and $\mathrm{Cl}^{-}$expressed in $\mathrm{mg} / \mathrm{l}$ were converted to equivalent per million (e.p.m), (which is equivalent to $\mathrm{mq} / \mathrm{l}$ ) and \%e.p.m [18]. Ion balance equation was applied to validate the accuracy of the chemical analyses where $\pm 5 \%$ is acceptable [19]. Also, the reaction error of all groundwater samples was less than the accepted limit of $\pm 10 \%$ [20] as in Table1 1 .

To achieve these objectives a speciation model has been used to determine the degree of saturation of groundwater with respect to some minerals using WATEQ4F program [21]. Along with the application of the Gibb's ratio to assess the functional sources of dissolved chemical constituents and to recognize the main processes governing the groundwater chemistry of the study area. Hydrochemical facies interpretation is used to determine flow pattern and origin of chemical histories of groundwater by plotting of the major cations and anions on the Piper diagram [22]. The assessment of groundwater for irrigation purposes based on different irrigation indices is carried out includes SAR, RSC, \% Na, residual sodium bicarbonate (RSBC), Permeability Index (P.I) Potential Salinity (P.S) ), Salinity hazard, magnesium ratio (MgR), Kelly's ratio (KR), and chloroalkaline index (CAI-1). Wilcox diagram (1955), and Doneen permeability index $[23,24]$ also have been utilized for classification of groundwater for irrigation. The spatial distribution of TDS, TH, RSC, SAR, gypsum and calcite parameters, were illustrated using ArcGIS10 software.

\subsection{Mechanisms of Controlling Groundwater Chemistry}

It is important to study the relationship between the water chemistry and the aquifer lithology. Gibb's [25] suggested a diagram that represents the ratio of dominant anions and cations plotted against the value of TDS. These ratios can be divided into two formula, the first ratio is for the cations $\left[\left(\mathrm{Na}^{+}+\mathrm{K}^{+}\right) /\left(\mathrm{Na}^{+}+\mathrm{K}^{+}+\mathrm{Ca}^{2+}\right)\right]$, and the second ratio is for the anions, $\mathrm{Cl}^{-} /\left(\mathrm{Cl}^{-}+\mathrm{HCO}^{-}\right)$ as a function of TDS. This diagram is widely used to evaluate the functional sources of dissolved constituents such as precipitation-dominance, rock-dominance, and evaporation-dominance. The chemical analyses of the study area are plotted in the Gibb's diagram as shown in Fig. 2, and showed that the predominant samples fall into the category of rock-water interaction field and few samples are located in evaporation-dominance field, which revealed that the chemical weathering of rockforming minerals are influencing the groundwater quality by dissolution of rock through which there is circulation, while the data in the evaporation-dominance field indicate that the increasing ions of $\mathrm{Na}^{+}$and $\mathrm{Cl}^{-}$are in relation with the increasing of the TDS.

Table.1: Chemical analysis results of the Al-Shagaya Field - C, $(\mathrm{mg} / \mathrm{l})$

\begin{tabular}{|c|c|c|c|c|c|c|c|c|c|c|}
\hline $\begin{array}{c}\text { Well } \\
\text { No. }\end{array}$ & $\begin{array}{c}\mathbf{E C} \\
\boldsymbol{\mu m o h s} / \mathbf{c m}\end{array}$ & $\mathbf{T D S}$ & $\mathbf{T . H a r d}$ & $\mathbf{N a}^{+}$ & $\mathbf{K}^{+}$ & $\mathbf{C a}^{2+}$ & $\mathbf{M g}^{2+}$ & $\mathbf{C l}^{-}$ & $\mathbf{S O}_{4}^{-}$ & $\mathbf{H C O}^{-}$ \\
\hline C-1 & 3340 & 2644 & 1308 & 360 & 12.0 & 338 & 113 & 476 & 1247 & 126 \\
\hline C-2 & 3460 & 2736 & 1332 & 365 & 11.5 & 323 & 128 & 517 & 1262 & 131 \\
\hline C-3 & 3680 & 2883 & 1379 & 335 & 10.5 & 330 & 135 & 535 & 1218 & 126 \\
\hline C-4 & 3700 & 2864 & 1370 & 470 & 12.0 & 338 & 128 & 489 & 1363 & 145 \\
\hline
\end{tabular}




\begin{tabular}{|c|c|c|c|c|c|c|c|c|c|c|}
\hline $\mathrm{C}-10$ & 3330 & 2662 & 1355 & 345 & 12.0 & 345 & 120 & 439 & 1276 & 136 \\
\hline C-11 & 3720 & 2933 & 1379 & 355 & 12.0 & 330 & 135 & 520 & 1247 & 148 \\
\hline C-12 & 3850 & 3121 & 1460 & 375 & 12.0 & 338 & 150 & 535 & 1276 & 149 \\
\hline C-13 & 3430 & 2773 & 1411 & 305 & 11.5 & 330 & 143 & 442 & 1218 & 140 \\
\hline C-14 & 3450 & 2773 & 1411 & 295 & 11.0 & 330 & 143 & 451 & 1247 & 140 \\
\hline C-19 & 3410 & 2694 & 1478 & 345 & 11.5 & 345 & 150 & 348 & 1247 & 134 \\
\hline C-20 & 3310 & 2690 & 1209 & 345 & 12.0 & 323 & 98 & 467 & 1276 & 133 \\
\hline C-21 & 3430 & 2921 & 1466 & 345 & 12.3 & 347 & 146 & 556 & 1276 & 176 \\
\hline C-22 & 3390 & 2684 & 1478 & 340 & 12.0 & 345 & 150 & 429 & 1247 & 134 \\
\hline C-23 & 3430 & 2686 & 1449 & 345 & 11.5 & 345 & 143 & 455 & 1218 & 129 \\
\hline C-28 & 3360 & 2664 & 1337 & 325 & 12.0 & 338 & 120 & 439 & 1247 & 130 \\
\hline C-29 & 3340 & 2648 & 1375 & 340 & 12.0 & 353 & 120 & 458 & 1276 & 131 \\
\hline C-30 & 3500 & 2756 & 1288 & 395 & 13.0 & 330 & 113 & 467 & 1276 & 148 \\
\hline C-31 & 3360 & 2646 & 1375 & 330 & 12.5 & 353 & 120 & 448 & 1276 & 138 \\
\hline $\mathrm{C}-32$ & 4060 & 3232 & 1549 & 460 & 16.5 & 398 & 135 & 505 & 1595 & 154 \\
\hline C-37 & 3510 & 2734 & 1262 & 395 & 12.0 & 308 & 120 & 467 & 1276 & 153 \\
\hline C-38 & 3330 & 2660 & 1370 & 325 & 12.0 & 338 & 128 & 420 & 1276 & 141 \\
\hline C-39 & 3370 & 2690 & 1387 & 330 & 12.0 & 345 & 128 & 439 & 1276 & 140 \\
\hline $\mathrm{C}-40$ & 3360 & 2672 & 1355 & 335 & 12.0 & 345 & 120 & 429 & 1334 & 144 \\
\hline C-41 & 3880 & 3042 & 1370 & 445 & 15.0 & 338 & 128 & 542 & 1450 & 158 \\
\hline C-105 & 3410 & 2694 & 1478 & 346 & 11.5 & 345 & 150 & 438 & 1247 & 134 \\
\hline C-106 & 3380 & 2672 & 1478 & 340 & 12.0 & 345 & 150 & 439 & 1247 & 138 \\
\hline C-107 & 3390 & 2694 & 1370 & 340 & 12.0 & 338 & 128 & 429 & 1276 & 141 \\
\hline C-108 & 3370 & 2708 & 1375 & 335 & 12.0 & 353 & 120 & 412 & 1363 & 148 \\
\hline C-109 & 3310 & 2646 & 1346 & 340 & 12.0 & 353 & 113 & 458 & 1247 & 125 \\
\hline $\mathrm{C}-110$ & 3320 & 2474 & 1189 & 350 & 12.0 & 315 & 98 & 467 & 1247 & 126 \\
\hline C-111 & 3400 & 2712 & 1339 & 350 & 12.0 & 323 & 143 & 467 & 1334 & 142 \\
\hline C-112 & 3360 & 2680 & 1332 & 330 & 12.0 & 232 & 128 & 429 & 1334 & 142 \\
\hline Min. & 3310 & 2474 & 1189 & 295 & 10.5 & 232 & 98 & 348 & 1218 & 125 \\
\hline Max. & 4060 & 3232 & 1549 & 470 & 16.5 & 398 & 150 & 556 & 1595 & 176 \\
\hline Ave. & 3467 & 2753 & 1377 & 354 & 12.13 & 336.16 & 129.50 & 462.87 & 1287.34 & 140 \\
\hline
\end{tabular}
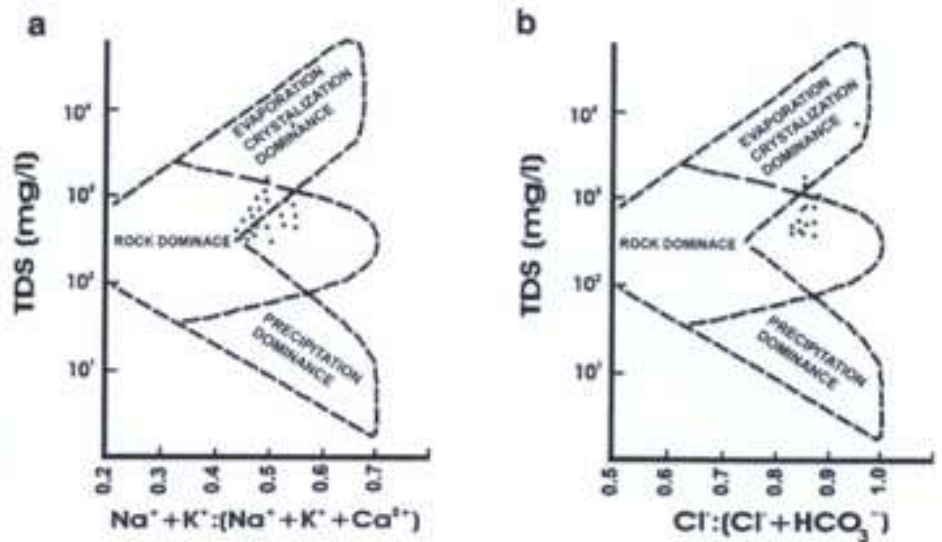

Fig.2: Gibb's diagram for controlling factor of groundwater quality in the study area 


\subsection{Hydrochemical Facies}

Hydrochemical facies interpretation using Piper trilinear diagram is a useful tool for determining the flow pattern and origin of chemical histories of groundwater. The Piper trilinear diagram is presented in Fig.3. Two principal hydrochemical water types have been delineated. These are $\mathrm{Ca}-\mathrm{Cl}$ and $\mathrm{Ca}-\mathrm{Mg}-\mathrm{Cl}$ water types respectively. The majority of the groundwater samples of the study area fall in $\mathrm{Ca}-\mathrm{Cl}$ water type which suggesting an end-product water. A few of the samples show $\mathrm{Ca}$ $\mathrm{Mg}-\mathrm{Cl}$ water type, indicat that alkaline earth $\left(\mathrm{Ca}^{2+}+\right.$ $\left.\mathrm{Mg}^{2+}\right)$ exceeds the alkaline $\left(\mathrm{Na}^{+}+\mathrm{K}^{+}\right)$and strong acid $\left(\mathrm{Cl}^{-}\right.$ and $\left.\mathrm{SO}_{4}{ }^{2-}\right)$ exceeds the weak acid $\left(\mathrm{HCO}_{3}^{-}\right.$and $\left.\mathrm{CO}_{3}{ }^{2-}\right)$.

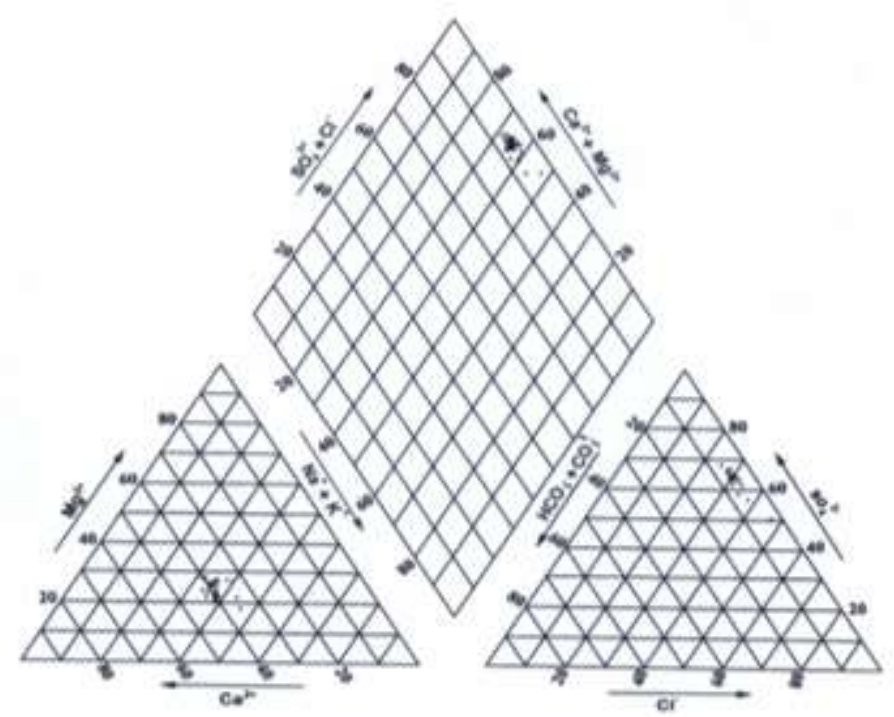

Fig.3: Piper trilinear diagram for the groundwater samples of the study area

\subsection{Geochemical Modeling}

Geochemical models are tools used to calculate chemical reaction in groundwater system such as dissolution and precipitation of solids, ion exchange, and sorption by clay minerals [26]. In this study, the speciation model has been applied to the groundwater samples of Al-Shagaya Field$\mathrm{C}$ to determine the saturation index (SI) of minerals. The SI for a given mineral measures the degree of saturation of that mineral with respect to the surrounding system. The degree of saturation index is defined as follow [27]:

$$
\mathrm{SI}=\log \frac{\mathrm{K}_{\mathrm{iap}}}{K_{s p}}
$$

Where "iap" is the ion activity product of the dissociated chemical species in solution, and " $\mathrm{K}_{\mathrm{sp}}$ " is the solubility product of the mineral. Where SI is $<0$, it indicates that the groundwater is under-saturated with respect to that particular mineral. When SI >0, it means that the groundwater is being saturated with respect to the mineral and incapable of dissolving more of the mineral. The over-saturation can also be produced by incongruent dissolution, common ion effect.

Table 2 shows the saturation indices of anhydrite, gypsum, halite, calcite and dolomite. Nearly, all groundwater samples of the study area are under saturated with respect to anhydrite, gypsum and halite and oversaturated with respect to calcite and dolomite.

Table.2: Results of thermodynamic speciation calculation of Al-Shagaya Field -C.

\begin{tabular}{|c|c|c|c|c|c|c|}
\hline \multirow{2}{*}{$\begin{array}{l}\text { Well } \\
\text { No. }\end{array}$} & Anhydrite & Gypsum & Halite & Calcite & Dolomite & \multirow{2}{*}{$\begin{array}{c}\mathrm{P}_{\mathrm{CO}_{2}} \\
\text { Atom. }\end{array}$} \\
\hline & $\mathrm{CaSO}_{4}$ & $\mathrm{CaSO}_{4} \cdot 2 \mathrm{H}_{2} \mathrm{O}$ & $\mathrm{NaCl}$ & $\mathrm{CaCO}_{3}$ & $\mathrm{CaMg}\left(\mathrm{CO}_{3}\right)_{2}$ & \\
\hline $\mathrm{C}-1$ & -0.30 & -0.33 & -5.44 & 0.20 & 0.20 & $4.19 \mathrm{E}-03$ \\
\hline C-2 & -0.32 & -0.35 & -5.40 & 0.19 & 0.27 & $4.35 \mathrm{E}-03$ \\
\hline $\mathrm{C}-3$ & -0.32 & -0.36 & -5.43 & 0.63 & 1.15 & $1.34 \mathrm{E}-03$ \\
\hline C-4 & -0.29 & -0.32 & -5.32 & 0.34 & 0.54 & $3.79 \mathrm{E}-03$ \\
\hline $\mathrm{C}-10$ & -0.28 & -0.32 & -5.50 & 0.19 & 0.20 & $5.08 \mathrm{E}-03$ \\
\hline C-11 & -0.32 & -0.35 & -5.41 & 0.45 & 0.80 & $3.06 \mathrm{E}-03$ \\
\hline C-12 & -0.31 & -0.35 & -5.38 & 0.75 & 1.42 & $1.49 \mathrm{E}-03$ \\
\hline C-13 & -0.32 & -0.36 & -5.55 & 0.24 & 0.40 & $4.64 \mathrm{E}-03$ \\
\hline
\end{tabular}




\begin{tabular}{|c|c|c|c|c|c|c|}
\hline C-14 & -0.31 & -0.35 & -5.55 & 0.14 & 0.19 & $5.80 \mathrm{E}-03$ \\
\hline C-19 & -0.29 & -0.34 & -5.60 & 0.24 & 0.39 & $4.42 \mathrm{E}-03$ \\
\hline C-20 & -0.30 & -0.34 & -5.47 & 0.49 & 0.75 & $2.20 \mathrm{E}-03$ \\
\hline C-21 & -0.24 & -0.28 & -4.94 & 0.11 & -0.01 & $2.91 \mathrm{E}-03$ \\
\hline C-22 & -0.29 & -0.33 & -5.75 & 0.24 & 0.40 & $4.43 \mathrm{E}-03$ \\
\hline C-23 & -0.31 & -0.34 & -5.48 & 0.32 & 0.53 & $3.37 \mathrm{E}-03$ \\
\hline C-28 & -0.30 & -0.33 & -5.52 & 0.21 & 0.26 & $4.33 \mathrm{E}-03$ \\
\hline C-29 & -0.28 & -0.31 & -5.49 & 0.62 & 1.05 & $1.69 \mathrm{E}-03$ \\
\hline C-30 & -0.30 & -0.34 & -5.41 & 0.25 & 0.32 & $4.93 \mathrm{E}-03$ \\
\hline C-31 & -0.27 & -0.31 & -5.51 & 0.25 & 0.32 & $4.58 \mathrm{E}-03$ \\
\hline C-32 & -0.18 & -0.22 & -5.33 & 0.31 & 0.48 & $5.04 \mathrm{E}-03$ \\
\hline C-37 & -0.33 & -0.37 & -5.41 & 0.33 & 0.35 & $5.10 \mathrm{E}-03$ \\
\hline C-38 & -0.29 & -0.24 & -5.54 & 0.34 & 0.55 & $3.71 \mathrm{E}-03$ \\
\hline C-39 & -0.29 & -0.32 & -5.52 & 0.35 & 0.55 & $3.67 \mathrm{E}-03$ \\
\hline C-40 & -0.27 & -0.31 & -5.52 & 0.32 & 0.45 & $3.46 \mathrm{E}-03$ \\
\hline C-41 & -0.27 & -0.31 & -5.31 & 0.22 & 0.30 & $5.78 \mathrm{E}-03$ \\
\hline C-105 & -0.30 & -0.34 & -5.50 & 0.23 & 0.38 & $4.40 \mathrm{E}-03$ \\
\hline C-106 & -0.30 & -0.34 & -5.51 & 0.25 & 0.41 & $4.55 \mathrm{E}-03$ \\
\hline C-107 & -0.29 & -0.33 & -5.52 & 0.25 & 0.35 & $4.68 \mathrm{E}-03$ \\
\hline C-108 & -0.25 & -0.29 & -5.54 & 0.28 & 0.36 & $4.92 \mathrm{E}-03$ \\
\hline C-109 & -0.28 & -0.32 & -5.49 & 0.22 & 0.22 & $4.15 \mathrm{E}-03$ \\
\hline C-110 & -0.31 & -0.35 & -5.46 & 0.37 & 0.51 & $2.64 \mathrm{E}-03$ \\
\hline C-111 & -0.30 & -0.34 & -5.47 & 0.22 & 0.37 & $4.71 \mathrm{E}-03$ \\
\hline C-112 & -0.42 & -0.45 & -5.53 & 0.37 & 0.77 & $2.30 \mathrm{E}-03$ \\
\hline Min. & -0.42 & -0.45 & -5.75 & 0.11 & -0.01 & $1.34 \mathrm{E}-03$ \\
\hline Max. & -0.18 & -0.22 & -4.94 & 0.75 & 1.42 & $5.80 \mathrm{E}-03$ \\
\hline Ave. & -0.29 & -0.33 & -5.46 & 0.31 & 0.48 & $3.93 \mathrm{E}-03$ \\
\hline
\end{tabular}

The areal distribution map of gypsum of the study area is shown in Fig. 4 and exhibits that the medium values of gypsum are concentrated in the central part, while low values are found in the southeastern corner. In addition, high values of calcite is displays in Fig. 5 and concentrated in the central part of the study area indicating that dissolution / precipitation process of these carbonate minerals along the path flow may have influenced the chemical composition of the Al-Shagaya Field-C. The partial pressure of the carbon dioxide values
$\left(\mathrm{Pco}_{2}\right)$ range between $1.34 \times 10^{-3} \mathrm{~atm}$. and $5.8 \times 10^{-3} \mathrm{~atm}$., with an average value of $3.93 \times 10^{-3} \mathrm{~atm}$. This indicates that the groundwater of the Dammam aquifer become charged with $\mathrm{CO}_{2}$ during infiltration through the soil zones. Where, according to Appelo and Postma [28] when $\mathrm{PcO}_{2}$ values range between $10^{-2.5} \mathrm{~atm}$. and $10^{-6.4} \mathrm{~atm}$., it represents a closed system. Since the Dammam aquifer is acting as a confined to semi-confined aquifer, it is more likely that the groundwater represents a deep closed environment system.

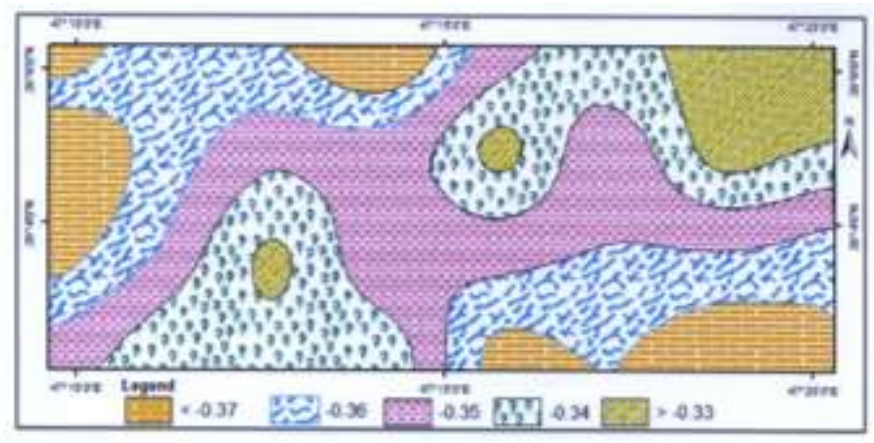

Fig.4: Spatial distribution of the saturation index of gypsum of the study area 


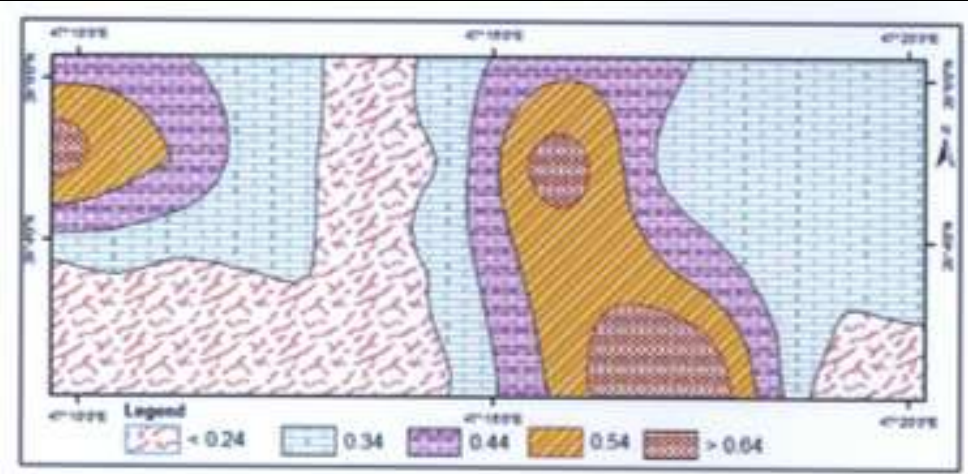

Fig.5: Spatial distribution of the saturation index of calcite of the study area

\subsection{Geochemical Evolution of Groundwater}

The initial composition of groundwater originates from rainfall with low concentrations of dissolved ions. During its return path to the ocean, the water composition is altered by rock weathering and evaporation causing more $\mathrm{Ca}^{2+}, \mathrm{Mg}^{2+}, \mathrm{Na}^{+}, \mathrm{SO}_{4}{ }^{2-}, \mathrm{HCO}_{3}{ }^{-}, \mathrm{Cl}^{-}$and $\mathrm{SiO}_{2}$ to be added. The concentration of these ions depends on the rock mineralogy that the water encounters and its rapidity along the flow path. The abundance of the major cations in Al-Shagaya Field-C is in the order $\mathrm{Na}^{+}>\mathrm{Ca}^{2+}>\mathrm{Mg}^{2+}>$ $\mathrm{K}^{+}$. The sequence of the anions is in order of $\mathrm{SO}_{4}{ }^{2}>\mathrm{Cl}^{-}>$ $\mathrm{HCO}_{3}{ }^{-}$. Calcium and magnesium present in the groundwater are mainly due to the dissolution of limestone, dolomite, gypsum and anhydrite, the most rock forming minerals of the Dammam aquifer of the study area. Calcium ions are derived also from cation exchange process [28].The concentration of calcium ions in the study area ranges from $232 \mathrm{mg} / \mathrm{l}$ to $398 \mathrm{mg} / \mathrm{l}$ and magnesium ranges from $98 \mathrm{mg} / \mathrm{l}$ to $150 \mathrm{mg} / \mathrm{l}$, with average values of $336 \mathrm{mg} / \mathrm{l}$ and $129 \mathrm{mg} / \mathrm{l}$ respectively. This indicates that the $\mathrm{Ca}^{2+}$ ion concentration in the study area is relatively higher than magnesium ion. The plot of $\mathrm{Ca}^{2+}+\mathrm{Mg}^{2+}$ Vs. $\left(\mathrm{HCO}_{3}{ }^{-}+\mathrm{SO}_{4}^{2-}\right)$ as in Fig. 6A, shows that the majority of the samples fall above the equiline indicating that the carbonate weathering is the dominant processes for supply of the calcium and magnesium ions to groundwater. The plot of $\left(\mathrm{Na}^{+}\right) \mathrm{Vs} .\left(\mathrm{Cl}^{-}\right)$of the groundwater samples of the study area presented in Fig. $6 \mathrm{~B}$, shows that the $\mathrm{Na} / \mathrm{Cl}$ ratio is greater than (1) which is typically indicates that the sodium was released from silicate weathering. The silicate weathering is also supported by the plot of $\mathrm{HCO}_{3}{ }^{-} \mathrm{Vs}$. $\mathrm{Na}^{+}$as shown in Fig. 6 $\mathrm{C}$, where all the samples fall below the equiline [29], this reveals that the carbonate and the silicate weathering are the dominant processes operating in the aquifer of the study area.
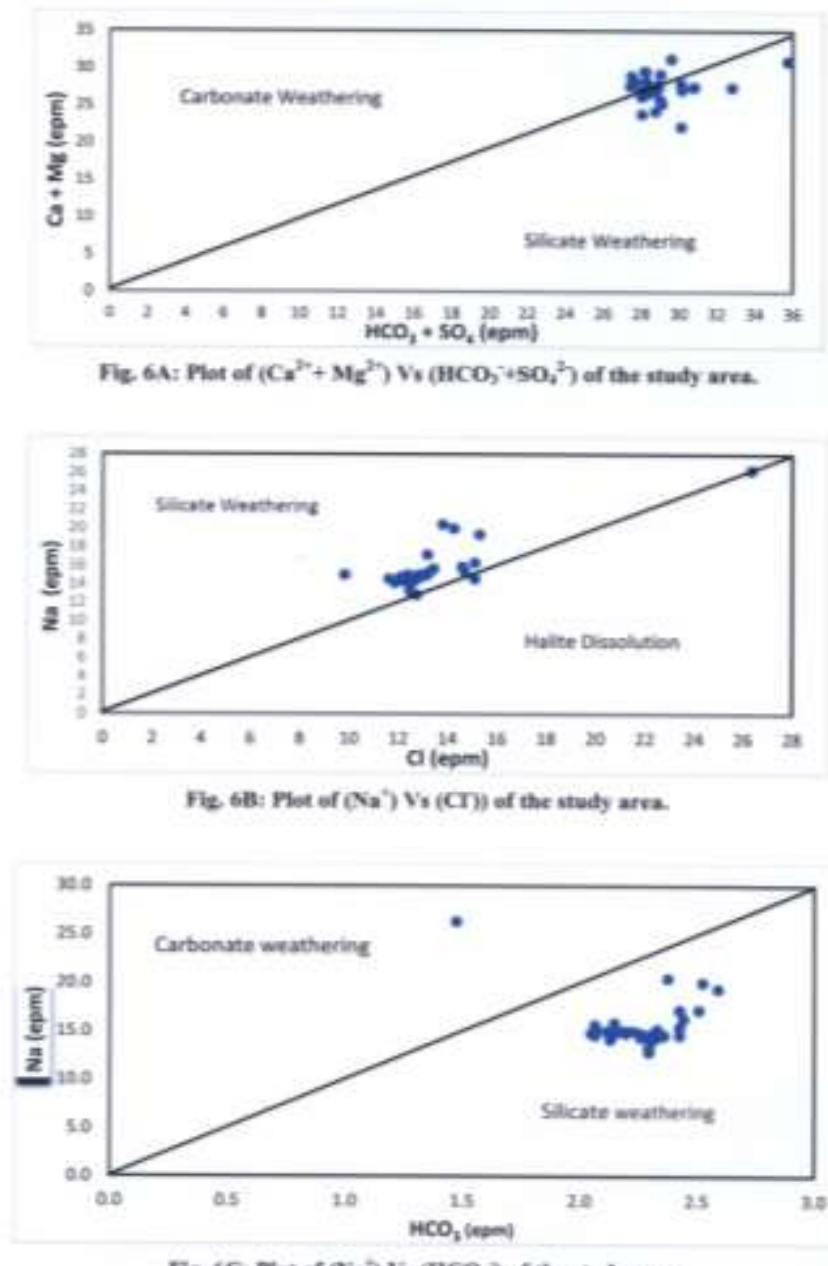

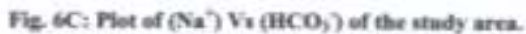

\section{DRINKING AND IRRIGATION WATER QUALITY}

The assessment of the suitability of groundwater for drinking and irrigation purposes can be determined through the parameters such as pH, EC, TDS, TH, RSC, residual sodium bicarbonate (RSBC), Permeability index (P.I), Potential Salinity (P.S), SAR, salinity hazard, magnesium ratio (MgR), \%Na, Kelley's ratio (KR), and chloro-alkaline index (CAI-1) as display in tables 1 and 3. 
Table.3: Irrigation water quality parameters for Al-Shagaya Field - C.

\begin{tabular}{|c|c|c|c|c|c|c|c|c|c|}
\hline Well No. & RSC & RSBC & P.I & P.S & SAR & $\mathrm{MgR}$ & $\% \mathrm{Na}$ & $\begin{array}{l}\text { Kelly's } \\
\text { ratio }\end{array}$ & CAI-1 \\
\hline C-1 & -24.10 & -14.80 & 40.88 & 26.41 & 4.33 & 35.53 & 37.17 & 0.60 & -0.19 \\
\hline C-2 & -24.50 & -13.97 & 40.78 & 27.72 & 4.35 & 39.51 & 37.08 & 0.60 & -0.11 \\
\hline C-3 & -25.51 & -14.40 & 37.99 & 27.77 & 3.92 & 40.28 & 34.36 & 0.53 & 0.02 \\
\hline C-4 & -25.02 & -14.49 & 45.96 & 27.98 & 5.52 & 38.43 & 42.46 & 0.75 & -0.50 \\
\hline $\mathrm{C}-10$ & -24.86 & -14.99 & 39.20 & 25.67 & 4.08 & 36.44 & 35.39 & 0.55 & -0.24 \\
\hline $\mathrm{C}-11$ & -25.15 & -14.04 & 39.52 & 27.65 & 4.16 & 40.28 & 35.65 & 0.56 & -0.07 \\
\hline $\mathrm{C}-12$ & -26.76 & -14.42 & 39.27 & 28.38 & 4.27 & 42.25 & 35.60 & 0.56 & -0.10 \\
\hline $\mathrm{C}-13$ & -25.94 & -14.17 & 35.62 & 25.15 & 3.53 & 41.67 & 31.75 & 0.47 & -0.09 \\
\hline C-14 & -25.94 & -14.17 & 34.94 & 25.70 & 3.42 & 41.67 & 31.04 & 0.45 & -0.03 \\
\hline C-19 & -27.36 & -15.02 & 37.00 & 22.80 & 3.90 & 41.75 & 33.46 & 0.51 & -0.56 \\
\hline C-20 & -22.00 & -13.94 & 42.07 & 26.46 & 4.32 & 33.34 & 38.00 & 0.62 & -0.16 \\
\hline $\mathrm{C}-21$ & -26.44 & -14.43 & 37.68 & 28.97 & 3.92 & 40.95 & 33.61 & 0.51 & 0.02 \\
\hline $\mathrm{C}-22$ & -27.36 & -15.02 & 36.69 & 25.08 & 3.85 & 41.75 & 33.12 & 0.50 & -0.25 \\
\hline C-23 & -26.86 & -15.10 & 37.42 & 25.51 & 3.94 & 40.59 & 33.89 & 0.52 & -0.19 \\
\hline C-28 & -24.61 & -14.74 & 38.16 & 25.37 & 3.87 & 36.92 & 34.33 & 0.53 & -0.17 \\
\hline C-29 & -25.34 & -15.47 & 38.45 & 26.20 & 3.99 & 35.91 & 34.73 & 0.54 & -0.17 \\
\hline C-30 & -23.34 & -14.04 & 43.64 & 26.46 & 4.79 & 36.08 & 39.70 & 0.67 & -0.33 \\
\hline C-31 & -25.22 & -15.35 & 37.90 & 25.92 & 3.87 & 35.91 & 34.05 & 0.52 & -0.16 \\
\hline C-32 & -28.44 & -17.34 & 42.37 & 30.85 & 5.09 & 35.86 & 38.93 & 0.65 & -0.43 \\
\hline C-37 & -22.73 & -12.86 & 44.24 & 26.46 & 4.84 & 39.11 & 40.21 & 0.68 & -0.33 \\
\hline C-38 & -25.08 & -14.56 & 37.70 & 25.13 & 3.82 & 38.43 & 33.79 & 0.52 & -0.22 \\
\hline C-39 & -25.45 & -14.92 & 37.70 & 25.67 & 3.85 & 37.95 & 33.85 & 0.52 & -0.18 \\
\hline $\mathrm{C}-40$ & -24.73 & -14.86 & 38.67 & 25.99 & 3.96 & 36.44 & 34.72 & 0.54 & -0.23 \\
\hline C-41 & -24.81 & -14.28 & 44.85 & 30.38 & 5.23 & 38.43 & 41.07 & 0.71 & -0.29 \\
\hline C-105 & -27.36 & -15.02 & 37.06 & 25.34 & 3.92 & 41.75 & 33.52 & 0.51 & -0.24 \\
\hline C-106 & -27.29 & -14.95 & 36.74 & 25.37 & 3.85 & 41.75 & 33.12 & 0.50 & -0.22 \\
\hline C-107 & -25.08 & -14.56 & 38.66 & 25.39 & 4.00 & 38.43 & 34.81 & 0.54 & -0.25 \\
\hline C-108 & -25.06 & -15.19 & 38.35 & 25.81 & 3.93 & 35.91 & 34.40 & 0.53 & -0.28 \\
\hline C-109 & -24.86 & -15.57 & 38.90 & 25.90 & 4.03 & 34.54 & 35.21 & 0.55 & -0.17 \\
\hline C-110 & -21.71 & -13.65 & 42.72 & 26.16 & 4.42 & 33.90 & 38.73 & 0.64 & -0.18 \\
\hline C-111 & -25.55 & -13.79 & 38.86 & 27.06 & 4.08 & 42.19 & 35.07 & 0.55 & -0.18 \\
\hline C-112 & -19.78 & -9.25 & 43.55 & 25.99 & 4.32 & 47.63 & 39.04 & 0.65 & -0.21 \\
\hline Min. & -28.44 & -17.34 & 34.94 & 22.80 & 3.42 & 33.34 & 31.04 & 0.45 & -0.56 \\
\hline Max. & -19.78 & -9.25 & 45.96 & 30.85 & 5.52 & 47.63 & 42.46 & 0.75 & 0.02 \\
\hline Ave. & -25.13 & -14.48 & 39.49 & 26.46 & 4.17 & 38.80 & 35.68 & 0.56 & -0.21 \\
\hline
\end{tabular}

\subsection{Drinking Water Quality}

The suitability of groundwater in the study area is evaluated for drinking by comparing with the standard guide line values [30]. According to WHO specifications, TDS up to $500 \mathrm{mg} / \mathrm{l}$ is the highest desirable and up to $1500 \mathrm{mg} / \mathrm{l}$ is the maximum permissible level. Based on this classification, the TDS of the groundwater of the study area ranges between 2474 and $3232 \mathrm{mg} / \mathrm{l}$ with an average value of $2753 \mathrm{mg} / \mathrm{l}$ which exceed the recommended limit. The areal distribution map of the TDS is plotted in Fig. 7, and showed that the minimum values are located in the southwestern corner of the study area. However, the major cations and anions composition of the study area are all above the standard guideline of the WHO for drinking purposes. Moreover, the total hardness of the study area is varying from 1189 to 1549 $\mathrm{mg} / \mathrm{l}$ as $\mathrm{CaCO}_{3}$, with an average value of $1377 \mathrm{mg} / \mathrm{l}$ as shown in Table 1. The areal distribution map of TH is shown in Fig. 8, where, the lower values of TH are found in the southwestern part, which seems to be the best quality zone in the study area. The analytical result of TH indicates that the groundwater of the study area is 
exceeding very hard water type according to [31] and as shown in Table 4. Therefore, according to TDS and TH standards the groundwater is not suitable for drinking purposes.

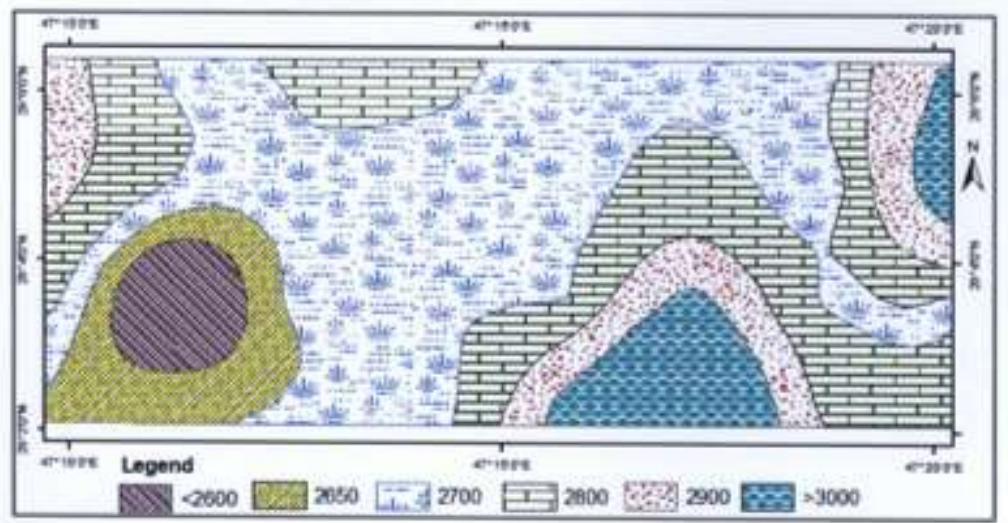

Fig.7: Spatial distribution of TDS of the study

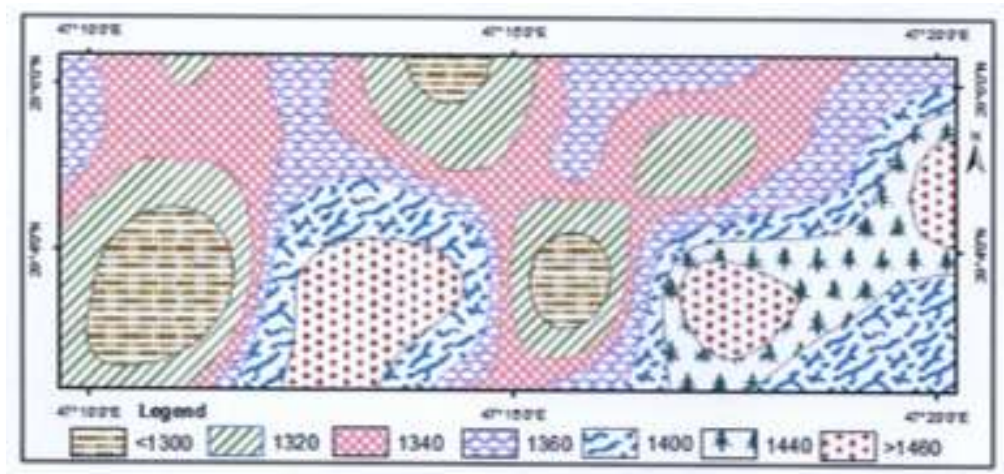

Fig.8: Spatial distribution of total hardness of the study area

Table.4: Water Classes (After Sawyer and McCarthy, 1967).

\begin{tabular}{|c|c|}
\hline $\begin{array}{c}\text { Total Hardness } \\
\text { as } \mathrm{CaCO}_{3}(\mathrm{mg} / \mathrm{l})\end{array}$ & Water Class \\
\hline$<75$ & soft \\
\hline $75-150$ & moderately hard \\
\hline $150-300$ & hard \\
\hline$>300$ & very hard \\
\hline
\end{tabular}

Water hardness causes more consumption of detergents at the time of cleaning, and some evidences indicate its role in heart disease [32]. The total hardness (TH) was determining by the following equation according to [33, 21 and 34].

$$
\mathrm{TH}=2.5 \mathrm{Ca}^{2+}+4.1 \mathrm{Mg}^{2+}
$$

Where $\mathrm{Ca}^{2+}$ and $\mathrm{Mg}^{2+}$ concentration are expressed in $\mathrm{mg} / \mathrm{l}$ as $\mathrm{CaCO}_{3}$. Hardness of water is by inhabitation of soap action in water due to precipitation of $\mathrm{Ca}^{2+}$ and $\mathrm{Mg}^{2+}$ salts like carbonate, sulphates and chlorides. Hardness of water causes scaling of pots, boilers and irrigation pipes. In order to examine the degree of correlation between the different chemical parameters affecting groundwater quality of the study area, the correlation matrix was determined between the different parameters as display in Table 5. It is found that there is a good correlation between $\mathrm{TH}$ and $\mathrm{Ca}^{2+}, \mathrm{Mg}^{2+}, \mathrm{Cl}^{-}$respectively, which indicates that the hardness of groundwater is mainly due to $\mathrm{CaCl}_{2}$ and $\mathrm{MgCl}_{2}$.

Table.5: Correlation matrix for different water quality parameters in the study area.

\begin{tabular}{|c|c|c|c|c|c|c|c|c|c|c|}
\hline & EC & TDS & Na & K & $\mathbf{C a}$ & $\mathbf{M g}$ & $\mathbf{C l}$ & $\mathbf{S O}_{4}$ & $\mathbf{H C O}_{3}$ & T.Hard \\
\hline EC & $\mathbf{0 . 0 0 0}$ & 0.985 & 0.889 & 0.656 & 0.541 & 0.148 & 0.908 & 0.478 & -0.316 & 0.493 \\
\hline TDS & 0.985 & $\mathbf{0 . 0 0 0}$ & 0.842 & 0.650 & 0.549 & 0.200 & 0.880 & 0.491 & -0.274 & 0.543 \\
\hline
\end{tabular}




\begin{tabular}{|c|c|c|c|c|c|c|c|c|c|c|}
\hline $\mathrm{Na}$ & 0.889 & 0.842 & 0.000 & 0.726 & 0.507 & -0.067 & 0.821 & 0.569 & -0.273 & 0.304 \\
\hline $\mathbf{K}$ & 0.656 & 0.650 & 0.726 & 0.000 & 0.503 & -0.115 & 0.486 & 0.847 & 0.089 & 0.316 \\
\hline $\mathrm{Ca}$ & 0.541 & 0.549 & 0.507 & 0.503 & 0.000 & 0.102 & 0.467 & 0.305 & -0.340 & 0.583 \\
\hline Mg & 0.148 & 0.200 & -0.067 & -0.115 & 0.102 & 0.000 & $\begin{array}{c}- \\
0.052\end{array}$ & -0.057 & 0.138 & 0.778 \\
\hline Cl & 0.908 & 0.880 & 0.821 & 0.486 & 0.467 & -0.052 & 0.000 & 0.242 & -0.565 & 0.273 \\
\hline $\mathrm{SO}_{4}$ & 0.478 & 0.491 & 0.569 & 0.847 & 0.305 & -0.057 & 0.242 & 0.000 & 0.354 & 0.255 \\
\hline $\mathrm{HCO}_{3}$ & -0.316 & -0.274 & -0.273 & 0.089 & -0.340 & 0.138 & $\begin{array}{c}- \\
0.565\end{array}$ & 0.354 & 0.000 & -0.129 \\
\hline T.Hard & 0.493 & 0.543 & 0.304 & 0.316 & 0.583 & 0.778 & 0.273 & 0.255 & -0.129 & 0.000 \\
\hline
\end{tabular}

\subsection{Irrigation Water Quality}

The suitability of groundwater for irrigation is depending on the effect of mineral composition of water on the soil and plants. The effect of the salt on soils causes change in soil structure, permeability, and hence, it effects on plant growth.

\subsubsection{Residual Sodium Carbonate}

Residual sodium carbonate (RSC) has been calculated to determine the hazards effects of carbonate and bicarbonate on quality of water for irrigation and is expressed by the equation:

$$
\mathrm{RSC}=\left(\mathrm{HCO}_{3}^{-}+\mathrm{CO}_{3}^{2-}\right)-\left(\mathrm{Ca}^{2+}+\mathrm{Mg}^{2+}\right)
$$

Whereas, all ionic concentrations are expressed in meq/l. The classification of irrigation water according to the RSC presents in Table 6 after [35], where water containing more than $2.5 \mathrm{meq} / \mathrm{l}$ of RSC are not suitable for irrigation, while those having $<1.25 \mathrm{meq} / \mathrm{l}$ is good for irrigation [36].
Table.6: Water classes based on RSC (after Richards, 1954).

\begin{tabular}{|c|c|}
\hline RSC value & Water quality \\
\hline$<1.25$ & suitable \\
\hline $1.25-2.5$ & marginal \\
\hline$>2.5$ & not suitable \\
\hline
\end{tabular}

Eaton (1950) indicated that if waters which are used for irrigation contain excess of $\mathrm{HCO}_{3}{ }^{-}+\mathrm{CO}_{3}{ }^{2-}$ than its equivalent $\mathrm{Ca}^{2+}+\mathrm{Mg}^{2+}$, there will be a residue of $\mathrm{Na}^{+}+$ $\mathrm{HCO}_{3}{ }^{-}$when evaporation takes place and the $\mathrm{pH}$ of the soil increase up to 3 [37]. When total carbonate levels exceed the total amount of calcium and magnesium the water quality diminished [38]. The calculated RSC values of the groundwater samples of the study area are ranged from -28.44 to $-19.78 \mathrm{meq} / \mathrm{l}$ with an average value of $25.2 \mathrm{meq} / \mathrm{l}$. Negative RSC indicates that sodium buildup is unlikely, since sufficient calcium and magnesium are in excess of what can be precipitated as carbonates [39]. Hence, the groundwater of the study area is safe for irrigation, and the minimum values of RSC are distributed in the southeastern as well as central part of the study area as displayed in Fig. 9.

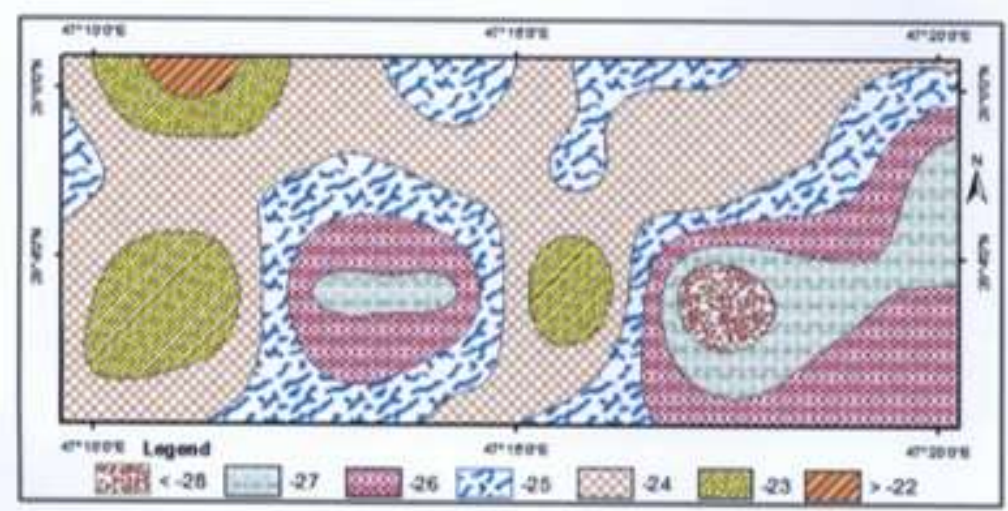

Fig.9: Spatial distribution of RSC of the study area 
4.2.2 Residual Sodium Bicarbonate (RSBC)

Residual sodium bicarbonate (RSBC) is calculated by the following formulae according to [40]:

$$
\mathrm{RSBC}=\mathrm{HCO}_{3}{ }^{-}-\mathrm{Ca}^{2+}
$$

It was found that the groundwater is considered satisfactory with $<5 \mathrm{meq} / \mathrm{l}$ for irrigation, according to the criteria set by [40] and [41]. In the study area, the values of the RSBC ranges between -17.34 and $-9.25 \mathrm{meq} / \mathrm{l}$ with an average value of $-14.48 \mathrm{meq} / \mathrm{l}$, which indicate that groundwater is good for irrigation.

\subsubsection{Permeability Index (P.I)}

The permeability of soil is affected by long-term use of irrigation water and is influenced by sodium, calcium, magnesium and bicarbonate contents in soil. Doneen (1964) set a criteria for assessing the suitability of water for irrigation based on permeability index (P.I), accordingly, waters can be classified as Class I, Class II and Class III. The Class I and Class II waters are categories as good for irrigation with $50-75 \%$ or more of maximum permeability. Whereas, Class III water is unsuitable with of $25 \%$ maximum permeability. Therefore, soil permeability is affected by consistent use of irrigation water which increases the presence of sodium, calcium, magnesium and bicarbonate in the soil [42].

The permeability index is used to measure the suitability of water for irrigation purpose when compared with the total ions in meq/l, it's expressed as follow:

$$
\mathrm{PI}=\frac{\mathrm{Na}^{+}+\sqrt{\mathrm{HCO}_{3}^{-}}}{\mathrm{Ca}^{2+}+\mathrm{Mg}^{2+}+\mathrm{Na}^{+}} * 100
$$

In the present study, the P.I of the groundwater samples ranged from $34.94 \%$ to $45.96 \%$ with a mean value of 39.49 $\%$, and it's observed that all the groundwater samples fall in class II category of Doneen Chart (Fig.10). Therefore, the groundwater of the study area is good for use in irrigation.

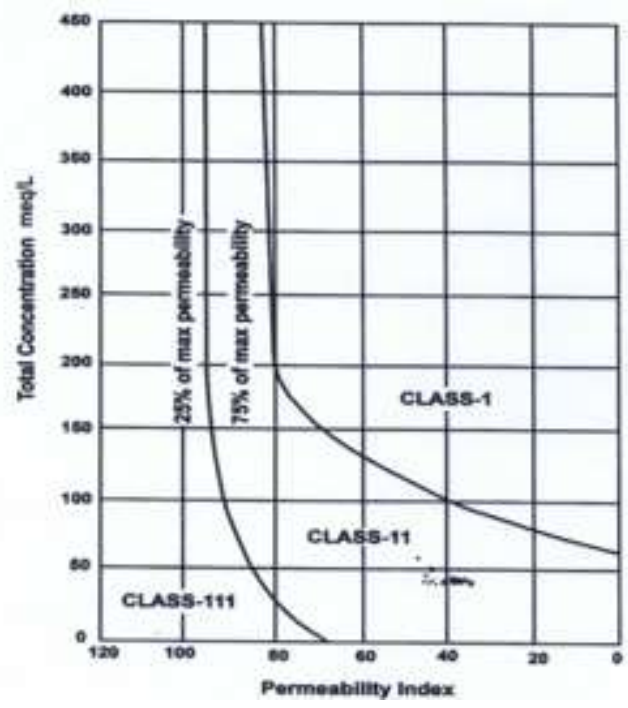

Fig.10: Showing Doneen's Chart of Permeability Index (after Doneen, 1964)

\subsubsection{Potential Salinity (P.S)}

Doneen, 1961 introduced an important parameter "Potential Salinity" for assessing the suitability of water for irrigation uses, which defined as chloride concentration plus half of the sulphate concentration expressed in meq/l.

$$
\text { Potential Salinity }=\mathrm{Cl}^{-}+1 / 2 \mathrm{SO}_{4}^{2-}
$$

On the basis of the potential salinity Doneen (1961) subdivided the irrigation water into three classes as presented in Table 7 . The potential salinity of the majority of the analyzed groundwater samples of the study area ranges between $22.8 \mathrm{meq} / \mathrm{l}$ and $30.85 \mathrm{meq} / \mathrm{l}$ with an average value of $26.46 \mathrm{meq} / \mathrm{l}$ indicates high values of potential salinity. However, it is found that the classification of the groundwater of the study area for irrigation purposes fall in Class III, therefore, the groundwater should be used in case of a soil of high permeability [43].

\begin{tabular}{|c|c|c|c|}
\hline $\begin{array}{r}\text { Soil } \\
\text { Characteristics }\end{array}$ & $\begin{array}{c}\text { Class } \\
\text { I }\end{array}$ & $\begin{array}{c}\text { Class } \\
\text { II }\end{array}$ & $\begin{array}{c}\text { Class } \\
\text { III }\end{array}$ \\
\hline $\begin{array}{l}\text { Soil of low } \\
\text { Permeability }\end{array}$ & $<3$ & $3-5$ & $>5$ \\
\hline $\begin{array}{l}\text { Soil of medium } \\
\text { Permeability }\end{array}$ & $<5$ & $5-10$ & $>10$ \\
\hline $\begin{array}{l}\text { Soil of high } \\
\text { Permeability }\end{array}$ & $<7$ & $7-15$ & $>15$ \\
\hline
\end{tabular}

Table.7: Classification of irrigation water based on potential salinity. 


\subsubsection{Sodium Adsorption Ratio (SAR)}

Sodium concentration is considered an important factor to express reaction with the soil and reduction in its permeability. Therefore, sodium adsorption ratio is considered as a better measure of sodium (alkali) hazard in irrigation water as it is directly related to the adsorption of $\mathrm{Na}^{+}$on soil, and is an important critera for estimating the suitability of the water for irrigation. SAR can be computed as follow:

$$
\mathrm{SAR}=\frac{N a^{+}}{\sqrt{\frac{C a^{2+}+M g^{2+}}{2}}}
$$

Where all ionic concentrations are expressed in meq/l. The SAR of the study area ranges between 3.42 and 5.52, with an average value of 4.17. According to the classifications of water based on SAR values [33, 35], the SAR values of all the study area are found to be $<10$, and are classified as being excellent for irrigation i.e $S_{1}$ category. The areal distribution map of the SAR values of the study area is presented in Fig.11, and it is exhibited that the lower values of SAR are concentrated in the southeastern and central part of the study field, which means that the groundwater of this part is suitable for irrigation.

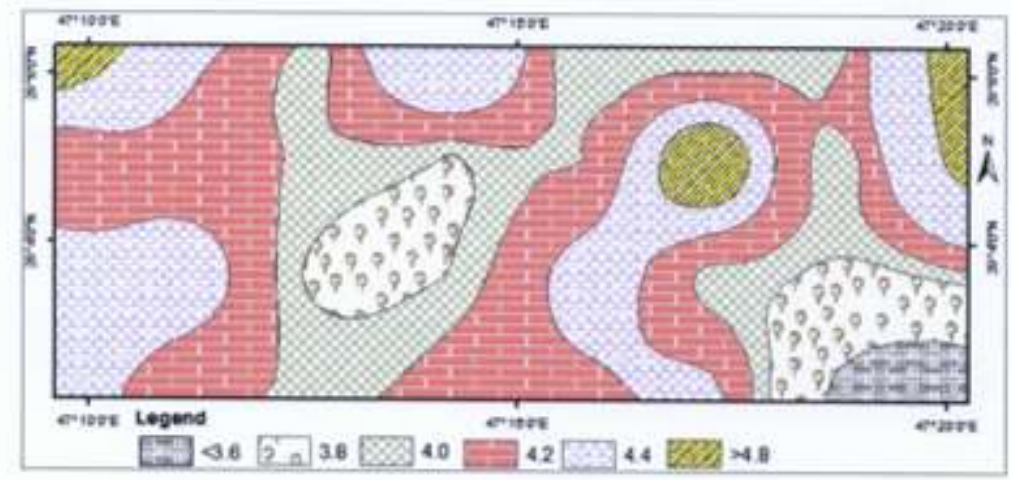

Fig.11: Spatial distribution of SAR of the study area

\subsubsection{Salinity Hazard}

The most important criteria regarding salinity and water availability to the plant is the total salt concentration. Since there exist a straight line correlation between electrical conductivity (EC) and total salt concentration of waters, the most expedient procedure to evaluate salinity hazard is to measure its electrical conductivity measured in $(\mu \mathrm{mohs} / \mathrm{cm})$ [44]. On the basis of salt concentration, US Salinity Laboratory Staff [35] divided the irrigation water into four classes as displayed in Table 8. It is found that the values of EC of the study area range from 3310 to $4060 \mu \mathrm{mohs} / \mathrm{cm}$ with an average value of $3467 \mu \mathrm{mohs} / \mathrm{cm}$ which is considered of $\mathrm{C} 4$ high salinity hazard class. For rating irrigation waters, the US salinity diagram was used, in which the SAR is plotted against EC as shown in Fig.12, where, all the samples of the study area fall in the category of the $\mathrm{C}_{4} \mathrm{~S}_{2}$, indicating high salinity/ medium sodium type. Therefore, the groundwater of $\mathrm{C}_{4}-\mathrm{S}_{2}$ class can be used with tolerant crops of clayey, sandy loam and loamy sand soil texture [45]. Based on these specifications, the groundwater of the study area is considered safe for irrigation.

Table.8: Salinity hazards of irrigation waters based on EC values (Richards, 1954).

\begin{tabular}{|c|c|c|}
\hline $\begin{array}{c}\text { EC of irrigation water } \\
(\mu \mathrm{mohs} / \mathrm{cm})\end{array}$ & Salinity Class & Salinity Hazards \\
\hline $100-250$ & $\mathrm{C} 1$ & very low \\
\hline $250-750$ & $\mathrm{C} 2$ & low \\
\hline $750-2250$ & $\mathrm{C} 3$ & medium \\
\hline $2250-4000$ & $\mathrm{C} 4$ & high salinity \\
\hline
\end{tabular}




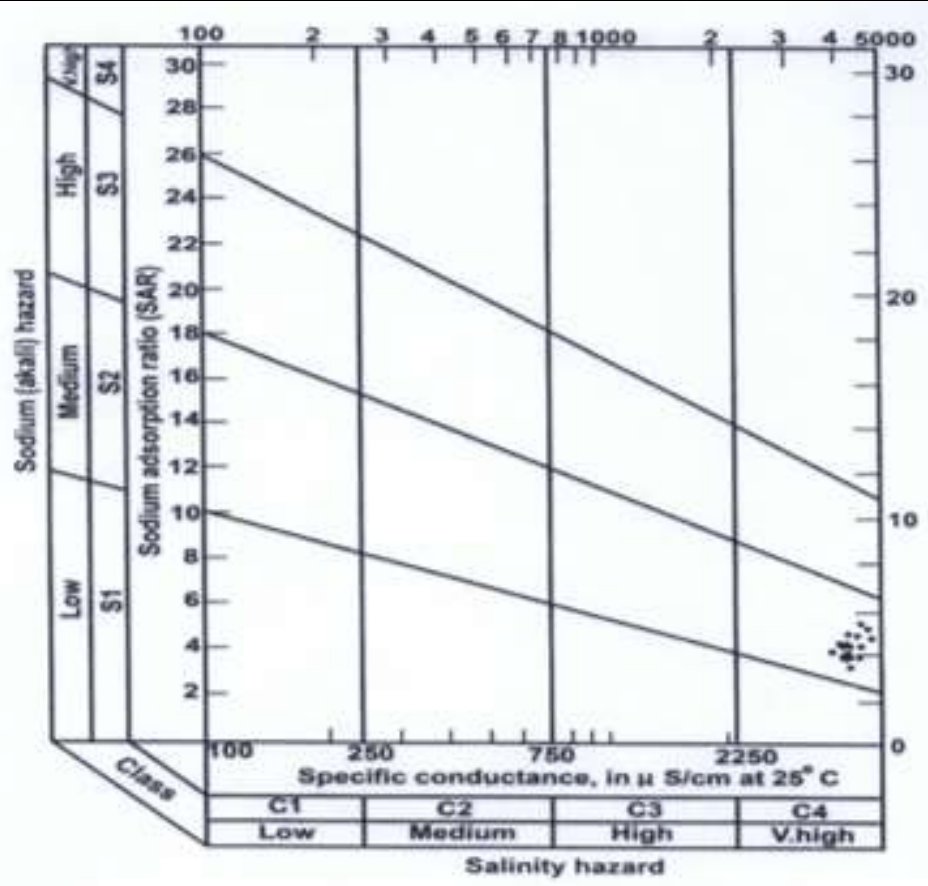

Fig.12: Showing USSL salinity hazard diagram of the study area

\subsubsection{Magnesium Ratio}

In most waters calcium and magnesium maintain a state of equilibrium. A ratio namely index of magnesium hazard was developed by [46]. According to this, high magnesium hazard value $>50 \%$ has an adverse affect on the crop yield as the soil becomes more alkaline, and effect on the agricultural yield.

$$
\mathrm{Mg} \text { ratio }=\frac{M g^{2+}}{\left(\mathrm{Ca}^{2+}+M g^{2+}\right)} \times 100
$$

Where all ionic concentration are expressed in meq/l.

In the study area, the magnesium hazard values falls in the range value of $33.34 \%$ to $47.63 \%$ with an average value of $38.8 \%$, i.e. magnesium hazard ratio $<50 \%$, which is recognized as suitable for irrigation.

\subsubsection{Sodium Percentage ( $\% \mathrm{Na})$}

Sodium is an important ion used for the classification of irrigation water due to its reaction with soil, reduces its permeability. The $\% \mathrm{Na}$ is computed as:

$$
\% \mathrm{Na}^{+}=\left(\frac{(\mathrm{Na}+\mathrm{K})^{+}}{\mathrm{Ca}^{2+}+\mathrm{Mg}^{2+}+\mathrm{K}^{+}+\mathrm{Na}^{+}}\right) \times 100
$$

Where, all ionic concentrations are expressed in meq/l. According to [47] in all natural waters $\% \mathrm{Na}$ is a common parameter to assess its suitability for irrigation purpose as shown in Table 9. If the concentration of $\mathrm{Na}^{+}$is high in irrigation water, $\mathrm{Na}^{+}$gets absorbed by clay particles, displacing $\mathrm{Mg}^{2+}$ and $\mathrm{Ca}^{2+}$ ions. This exchange process of $\mathrm{Na}^{+}$in water for $\mathrm{Ca}^{2+}$ and $\mathrm{Mg}^{2+}$ in soil reduces the permeability of soil and eventually results in poor internal drainage of the soil, and such soils are usually hard when dry $[48,49]$. The values of $\% \mathrm{Na}$ of the study area varies from $31 \%$ to $42.46 \%$ with an average value of $35.68 \%$ which fall in good to permissible category, showing that the groundwater of the study area is suitable for irrigation.

Table.9: Classification of groundwater based on $\% \mathrm{Na}$ (Wilcox, 1955).

\begin{tabular}{|c|c|}
\hline Water quality & Sodium \% \\
\hline Excellent & $<20$ \\
\hline Good & $20-40$ \\
\hline Permissible & $40-60$ \\
\hline Doubtful & $60-80$ \\
\hline Unsuitable & $>80$ \\
\hline
\end{tabular}

\subsubsection{Kelly's Ratio}

Kelly's ratio is used for the classification of water for irrigation purposes. A Kelly's index $(>1)$ indicates an excess level of sodium in waters [50]. Therefore, water with a KR $(<1)$ is suitable for irrigation. KR is calculated by using the formulae; where all the ions are expressed in $\mathrm{meq} / \mathrm{l}$.

$$
\text { Kelly's Ratio }=\frac{\mathrm{Na}^{+}}{\left(\mathrm{Ca}^{2+}+M \mathrm{~g}^{2+}\right)}
$$

The values of the KR in the present study varied between 0.45 and 0.75 with an average value of 0.56 which is $<1$. Accordingly, the groundwater of the study area is suitable for irrigation.

\subsubsection{Ion-Exchange Processes}

It is essential to identify the various changes in chemical composition occur in groundwater during its travel in subsurface [51]. This can be done by the computation of 
the chloro-alkaline index -1 which is suggested by [52] to indicate ion exchange between the groundwater and its host environment during residence or travel. The value of the index CAI-1, can be positive or negative. If the value is positive then it explains that the exchange of $\mathrm{Na}^{+}$and $\mathrm{K}^{+}$ions are from water with $\mathrm{Mg}^{2+}$ and $\mathrm{Ca}^{2+}$ ions of the rocks. And if the index is negative, then it means that there is an exchange $\mathrm{Mg}^{2+}$ and $\mathrm{Ca}^{2+}$ of water with $\mathrm{Na}^{+}$and $\mathrm{K}^{+}$ions from rocks, so the exchange is in indirect base indicating chloro-alkaline disequilibrium. The chloroalkaline index-1 is calculated using the following formulae:

$$
\text { Chloro-alkaline index }=\frac{\mathrm{Cl}^{-}-\left(\mathrm{Na}^{+}+\mathrm{K}^{+}\right)}{\mathrm{Cl}^{-}}
$$

Whereas, all ionic concentrations are expressed in meq/l. The chloro-alkaline index -1 is calculated for the groundwater samples of the study area and it has been found that CAI-1 values all are negative, and range from 0.56 to -0.21 , with an average value of -0.21 indicating that all the groundwater samples have indirect baseexchange reaction.

\section{CONCLUSION}

The interpretation of the hydrochemical analysis of Field$\mathrm{C}$ reveals that the groundwater is brackish and exceeding very hard. The sequence of the major ions is in the following order: $\mathrm{Na}^{+}>\mathrm{Ca}^{2+}>\mathrm{Mg}^{2+}>\mathrm{K}^{+}$and $\mathrm{SO}_{4}{ }^{2-}>\mathrm{Cl}^{-}>$ $\mathrm{HCO}_{3}^{-}$. Alkali earth exceeds alkalis and strong acids exceed weak acids. The dominated hydrochemical facies of groundwater is $\mathrm{Ca}-\mathrm{Cl}$ and $\mathrm{Ca}-\mathrm{Mg}-\mathrm{Cl}$ genetic water types. The determination of the saturated index indicated that all groundwater samples of the study area were under-saturated with respect to the sulphate minerals, and oversaturated with respect to carbonate minerals. Gibb's plot revealed that the chemical weathering of rockforming minerals is the dominant process, where there is an interaction between rock chemistry and percolating waters in the subsurface. The irrigation parameters reveal that the groundwater is good and suitable for irrigation and concentrated along the southwestern and central parts of the study area. Meanwhile, the major ions compositions in groundwater indicate that the water is not suitable for drinking purpose.

\section{ACKNOWLEDGMENTS}

The authors would like to thank the Ministry of Electricity and Water for providing the chemical analyses of the Al-Shagaya Field-C. In addition, authors are highly appreciated to the distinguished reviewers for their insightful suggestions and comments.

\section{REFERENCES}

[1] Al-Ruwaih, F.M. (2001). Hydrochemical investigation on the clastic and carbonate aquifers, Kuwait Bulletin of
Engineering Geology and the Environment. vol. 60, 4, $310-314$.

[2] Kumari, B. V., Murthy, Y. L. N., \& Machiraju, P. V. S, (2015). Quality Evaluation of soil in Coringa Mangroves region in East Godarari District for Assessement of its Quality for Application. International Journal.of Engineering and Technical Research. ISSN:2321-0869, vol. 3, Issue-5, 461468.

[3] Chemura, A., Kutywayo, D., Chagwesha, T.M., \& Chidoko, P. (2014). An assessment of irrigation water quality and selected parameters at Mutema irrigation scheme, Zimbabwe. Journal of water Resources and protection. vol. 6, $130-140$.

[4] Yidana, M.S., Sakyi, P.A., \& Starmp, G. (2011). Analysis of the salinity suitability of surface water for irrigation purposes: The Southwest and Coastal River System in Ghana. Journal of Water Resources and Protection. vol.3, no. 1, $695-710$.

[5] Aza-Gnandji, CD R., Xu, Y., Raitt, L., \& Levy, J. (2013). Salinity of irrigation water in Phillippi farming area of the Cape Flats, Cape Town, South Africa. Water of South Africa, Vol. 39, no. 2, 199 209.

[6] Dastorani, M.T., Heshmati, M., \& Sadeghzadeh, M.A. (2010). Evaluation of the efficiency of surface and subsurface irrigation in dryland environments. Irrigation and Drainage. 559, 129 - 137.

[7] Al-Enezi, A. H. (2015). Groundwater quality and its effect on soil in Abdalli area in the state of Kuwait. Kingdom of Bahrain. Arabian Gulf University. College of Graduate Studies M.sc. Thesis, 75pp.

[8] Ramesh, k., \& Elango, L. ( 2012). Groundwater quality and suitability for domestic and agriculture use in Tondiar river basin, Tamil Nadu, India. Environmental Monitoring Assessement. 184, 3887 -3899 .

[9] Lakshmi, J. K., Machiraju, P.V.S., \& UdayaBhaskar, P. (2014). Physicochemical and microbial characterization of subsurface waters near a non point source for assessment of quality for end use applications. International Journal of Current Chemical sciences. vol. 3, Issue 1, 4-11.

[10] Narany, T. S., Ramli, M. F., Aris, A. Z., Sulaiman, W. N. Z., \& Fakharian, K. (2012). Assessment of groundwater quality for irrigation purpose in Amol Plaine, Iran. $6^{\text {th }}$ Internatioal symposium on Advances in Science and Technology, Malaysia, Kuala Lumpur, 21 - 25 March.

[11] Rama Rao, D., Satyanarayana, T., \& Machiraju, P. V. S. (2012). Assessment of groundwater quality for application in KaKinada coast. Pelagia Research Library. Der Chemica Sinica. vol. 3, 1, 287-291. 
[12]Fuchs, W., Gattinger, T.E., \& Holzer, H.F. (1968). Explanatory text to the synoptic geologic map of Kuwait. A surface geology of Kuwait and the Neutral zone. Geological Survey of Austria, Vienn, $87 \mathrm{pp}$.

[13] Omar, S.S., Al-Yaqubi, A., \& Senay, Y. (1981). Stratigraphy of the Kuwait-Basrah area. In: Hibitat of Oil. American Association of Petroleum Geology Bulletin. 22,1252-1278.

[14] Al-Sulaimi, J.S., \& Al-Ruwaih, F.M. (2005). Geology and natural resources of Kuwait. Academic Publication Council, Kuwait University, 501 pp.

[15] Al-Ruwaih, F.M., \& Ben-Essa, S.A. (2004). Hygrogeological and hydrochemical study of the AlShagaya Field-F, Kuwait. Bulletin of Engineering Geology and Environment. 63,57-70.

[16] Al-Ruwaih, F.M., Talebi, L., \& Hadi, K.M. (2005). Major geological processes in the evolution of Eocene carbonate aquifer, Kuwait. Kuwait Journal of Science and Engineering. 32, 1,119-144.

[17] Al-Ruwaih, F.M., Al-Hmoud, J. M., \& Al-Dhaferri, Z.M. (2012). Characterization and evaluation of the confined limestone aquifer in Kuwait. Journal of the Gulf and Arabian Peninsula Studies. vol.3, no.146, 17-49.

[18] Fetter, W.C. (2001). Applied hydrogeology. $4^{\text {th }}$ ed. Prentice-Hall, Inc. 598pp.

[19] Saether, O.M., \& De-Caritat, P. (1997). Geochemical processes, weathering and groundwater recharge in catchments. Balkema, Rotterdam. The Netherlands, 400pp.

[20] Hem, J.D. (1991). Study and interpretation of chemical characteristics of natural Water. $\left(3^{\text {rd }} \mathrm{ed}\right)$. Book 2254: Scientific publ. Jodhpur, India.

[21] Ball, J.W., \& Nordstrom, D.K. (1992). Geochemical model to calculate speciation of major, trace and redox elements in natural waters. Report, U.S. Geological Survey, International Groundwater Modeling Center, U.S.A.

[22] Piper, A.M. (1953). A graphical procedure in geochemical interpretation of water analyses. Trans. Am. Geophys. Union . 25, 914-923.

[23] Doneen, L.D. (1961). The influence of crop and soil on percolating water. Proceedings of Groundwater Recharge Conference, California, U.S.A.

[24] Doneen, L.D. (1964). Notes on water quality in agriculture. In Davis, C.A., Water Science and Engineering, University of California.

[25] Gibbs, R.T. (1970). Mechanisms controlling world's water chemistry. Science, vol., 170, 1088-1090.

[26] Plummer, L.N. (1984). Geochemical modeling: A comparison of forward and inverse method. In: Hitchon, B., \& Wallick, E.I. (Eds.). Proceeding of
First Canadian Conference of Hydrogeology: Partial application of groundwater geochemistry. National Water Well Association, Canada, Worthington, $\mathrm{OH}$, U.S.A.

[27] Deutsch, W.J. (1997). Groundwater geochemistry: fundamentals and applications to contamination. Lewis Publishers, New York, , U.S.A, 221pp.

[28] Appelo, C.A.J., \& Postma, D. (2005). Geochemistry, groundwater and pollution. Balkema, Rotterdam, The Netherlands, 649pp.

[29] Datta, P.S., \& Tyagi, S.K. (1996). Major ion chemistry of groundwater in Delhi area: chemical weathering processes and groundwater flow regime. J. Geol. Soc. India. 47,179-188

[30] WHO. (2008). Guidelines for drinking-water quality [Electronic Source]: incorporations, $3^{\text {rd }}$ ed. WHO, Geneva, 515pp.

[31] Sawyer, G.N., \& McCarthy, D.L. (1967). Chemistry of sanitary engineers, $2^{\text {nd }}$ ed., Mc Grow Hill, New York, 518pp.

[32] Schroeder, H.A. (1960). Relations between hardness of water and death rate from certain chronic and degenerative diseases in the United States, J. Chron. Disease. 12,586-591.

[33] Todd, D.K., \& Mays, L.W. ( 2005). Groundwater hydrology. John wiley \& sons, Inc, $3^{\text {rd }}$ ed., 636 pp.

[34] Raghunath, H.M. (2007). Groundwater. $3^{\text {rd }}$ ed., New age International Publishers, 504pp.

[35] Richards, L.A. (1954). Diagnosis and improvement of saline and alkaline soils. US Department of Agriculture Hand Book, 60pp.

[36] Taqveem, A.K., \& Abbasi, A.M. (2013). Synthesis of parameters used to check the suitability of water for irrigation purposes. International J. of Environmental Science, vol.3, no.6 , 2031-2038.

[37]Eaton, E.M. (1950). Significance of carbonate in irrigation water. Soil Sci. 69, 12-133.

[38] Sundaray, S.K., Nayak, B.B. , \& Bhatta, D. (2009). Environmental studies on river waters quality with reference to suitability for agricultural purposes: Mahanadi river esturarine system, India- a case study, Environmental Monitoring and Assessment, $155,227-243$.

[39] Satyanarayanan, M., Balaram, V., Al Hussin, M. S., Al Jemaili, M. A., Rao, T.G., Mathur, R., Dasaram, B., \& Ramesh, S.L. (2007). Assessment of groundwater quality in structurally deformed granitic terrain in Hyderabad, India.. Environmental Monitoring and Assessment, 113, 117-127.

[40] Gupta, S.K. , \& Gupta, I.C. (1987). Management of saline soils and water. Oxford and IBH Publication Coy, New Delhi, India, 399pp. 
[41] Oladeji, O.S., Adewoye, A.O., \& Adegbola, A.A. (2012). Suitability assessment of groundwater resources for irrigation around Otte Village, Kwara State, Nigeria. Int. J. of Applied Sciences and Engineering Research, Vol. 1, Issue 3, 434-445.

[42] Chandu, S. N., Subbarao, N.V., \& Prakash, S. R. (1995). Suitability of groundwater for domestic and irrigation purposes in some part of Jhansi District, U. P. Bhujal Newa, 10, 1, 12-17.

[43]El-Nakhal, H.A., \& Ashour, M.M. (1986). Water quality of the area west of Karak City, Jordan. Qatar Univ. Sci. Bull, 6, 273-285.

[44] Chhabra, R. (1996). Soil salinity and water quality. A.A. Balkema Publishers, U.S.A. 284pp.

[45] Kanwar, J.S., \& Kanwar, B.S. (1969). Quality of irrigation waters. Trans. $9^{\text {th }}$ Intern. Congr. Soil Sci.1, 391-403.

[46] Paliwal, K.V. (1972). Irrigation with saline water. Monogram No.2 (new series). I A R I, New Delhi, 198pp.

[47] Wilcox, L.V. (1955). Classification and use of irrigation waters. US Department of Agriculture, Washington. D.C, 19pp.

[48] Collins, R., \& Jenkins, A. (1996). The impact of agricultural land use on stream chemistry in the middle hills of the Himalayas, Nepal. J. Hydrology, 185,71-86.

[49] Saleh, A., Al-Ruwaih, F. M., \& Shehata, M. (1999). Hydrogeochemical processes operating within the main aquifers of Kuwait. J. Arid Environments, 42,195-209.

[50] Kelly, W.P. (1951). Alkali soils- their formation properties and reclamation. $3^{\text {rd }}$ ed. Reinhold publication, New York, U.S.A, 92pp.

[51] Al-Ahmdi, M. E. (2013). Hydrochemical characterization of groundwater in wadi Sayyah, Western Saudi Arabia . Applied Water Science. 3, 721-732.

[52] Schoeller, H .(1977). Geochemistry of groundwater. In groundwater Studies- An international guide for research and practice (ch. 15, p.p. 1-18 ) .Paris : UNESCO. 